\title{
The Myth of Nitrogen Fertilization for Soil Carbon Sequestration
}

\author{
S. A. Khan, * R. L. Mulvaney, T. R. Ellsworth, and C. W. Boast University of Illinois
}

Intensive use of $N$ fertilizers in modern agriculrure is motivated by the economic value of high grain yields and is generally perceived to sequester soil organic $C$ by increasing the input of crop residues. This perception is at odds with a century of soil organic $\mathrm{C}$ data reported herein for the Morrow Plots, the world's oldest experimental site under continuous corn (Zea mays $L$ ). After 40 to 50 yr of synthetic fertilization that exceeded grain N removal by 60 to $190 \%$, a net decline occurred in soil $\mathrm{C}$ despite increasingly massive residue $C$ incorporation, the dedine being more extensive for a con-soybean (Glycine max L. Merr) or corn-oats (Avena sativa L) -hay rotation than for continuous corn and of greater intensity for the profile $(0-46 \mathrm{~cm})$ than the surface soil. These findings implicate fertilizer $N$ in promoting the decomposition of crop residues and soil organic manter and are consistent with data from numerous cropping experiments. involving synthetic $N$ fertilization in the USA Corn Belt and elsewhere, although not with the interpreation usually provided. There are important implications for soil $C$ sequestration because the yield-based input of fertilizer $N$ has commonly exceeded grain $\mathrm{N}$ removal for corn production on fertile soils since the 1960 s. To mitigate the ongoing consequences of soil deterioration, atmospheric $\mathrm{CO}_{2}$ enrichment, and $\mathrm{NO}_{3}$ pollution of ground and surface waters. $\mathrm{N}$ fertilization should be managed by site-specific assessment of soil $\mathrm{N}$ availability. Current fertilizer $\mathrm{N}$ management practices, if combined with corn stover removal for bioenergy production, exacerbate soil $C$ loss:

Copyright $\Theta 2007$ by the American Society of Agronomy, Crop Science Society of America, and Soil Science Society of America. All rights reserved. No part of this periodical may be reproduced or transmitted in any form or by any means, electronic or mechanical, including photocopying, recording, or any information storage and retrieval system, without permission in writing from the publisher.

Published in J. Environ. Qual. 36:1821-1832 (2007).

doi:10.2134/jeq2007.0099

Received 2 Feb. 2007.

*Corresponding author (mpcnlink@gmail.com).

- ASA, CSSA, SSSA

677 S. Segoe Rd., Madison, WI 53711 USA
THE shift from biological- to chemical-based $\mathrm{N}$ management I that provided the impetus for modern cereal agriculture originated during the late 1940 s as synthetic $\mathrm{N}$ fertilizers became more widely available following World War II. By the 1950s, traditional legume-based rotations that had long been practiced in the Midwestern USA were being replaced by more intensive row cropping with corn as the principal source of grain production. The past five decades have seen a remarkable increase in corn yield and in the use of fertilizer N (USDA, 2007).

Despite the use of forage legumes, many Midwestern soils had suffered a serious decline in their content of $\mathrm{N}$ and organic matter by the mid-twentieth century, except in cases involving regular manuring. There was good reason for concern that this decline could adversely affect agricultural productivity and sustainability because organic matter plays a key role in maintaining soil aggregation and aeration, hydraulic conductivity, and water availability; cation-exchange and buffer capacity; and the supply of mineralizable nutrients. There were also important implications for atmospheric $\mathrm{CO}_{2}$ enrichment because soils represent the Earth's major surface $\mathrm{C}$ reservoir (Bolin, 1977).

With the introduction of chemical-based $\mathrm{N}$ management, a new strategy became available for increasing not only grain yield, but also the input of crop residues, which was assumed to be of value for maintaining soil organic matter (SOM) (Lyon et al., 1952; Melsted, 1954; Tisdale and Nelson, 1956). Ample fertilizer $\mathrm{N}$ was believed to promote humus formation by narrowing the $\mathrm{C} / \mathrm{N}$ ratio of carbonaceous residues and by providing a major elemental constituent (Lee and Bray, 1949; Millar and Turk, 1951; Melsted, 1954).

The effectiveness of the new management system could only be reliably assessed from long-term cropping experiments, several of which were using synthetic $\mathrm{N}$ by the 1960 s. Among these was a study at the Morrow Plots, the oldest experimental field in the USA, encompassing the world's longest period of cropping to continuous corn on the most productive soil order (Mollisols). Beginning in 1955, fertilization with commercial N, P, and K (NPK) was initiated for a series of unreplicated subplots to increase grain yield and to augment production of aboveground residues that would subsequently be incorporated rather than removed, for sequestering SOM and thereby sustaining agricultural productivity. The short-term effect was a dramatic yield

S. A. Khan, R. L. Mulvaney, T. R. Ellsworth, and C.W. Boast, Department of Natural Resources and Environmental Sciences, Turner Hall, 1102 S. Goodwin Ave., Univ. of Illinois, Urbana, IL 61801 . This study was performed with partial funding under Project 875397, illinois Agric. Exp. Stn, and with support generated through the ${ }^{15} \mathrm{~N}$ Analysis Service.

Abbreviations: HI, harvest index; HNPK, high NPK; ISNT, Illinois soil N test; NPK, fertilization with commercial $N, P$, and $K$; RSR, root-to-shoot ratio; SOC, soil organic $C_{\text {; }}$ SOM, soil organic matter. 


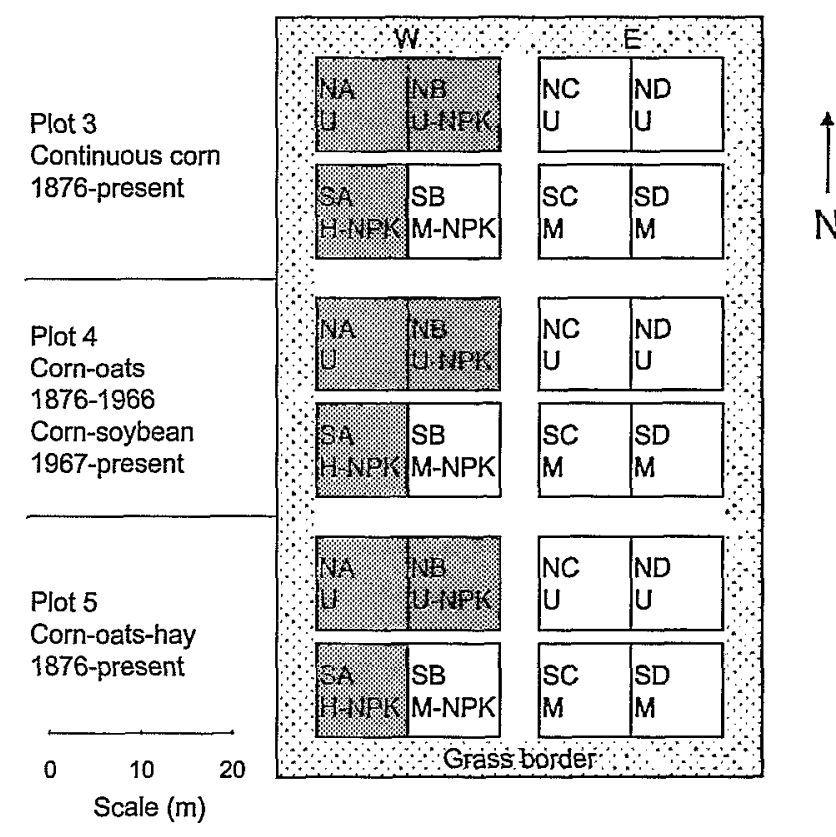

Fig. 1. Map of the Morrow Plots. U, unamended; U-NPK, unamended until 1955, currently fertilized for corn with $224 \mathrm{~kg} \mathrm{~N} \mathrm{ha}^{-1}$, Bray$1 \mathrm{P}=56 \mathrm{~kg} \mathrm{ha}^{-1}$, and exchangeable $\mathrm{K}=336 \mathrm{~kg} \mathrm{ha}^{-1} ; \mathrm{H}-\mathrm{NPK}$, treated with manure, limestone, and rock phosphate from 19041966 and subsequently fertilized for corn with $336 \mathrm{~kg} \mathrm{~N} \mathrm{ha}^{-1}$, Bray-1 $\mathrm{P}=112 \mathrm{~kg} \mathrm{ha}^{-1}$, and exchangeable $\mathrm{K}=560 \mathrm{~kg} \mathrm{ha}^{-1} ; \mathrm{M}-$ NPK, treated with manure, limestone, and rock phosphate from 1904-1954 and since fertilized as with the U-NPK treatment; $M$, manured. The subplots studied are shaded.

increase, up to $140 \%$ for a previously unfertilized plot under continuous corn since 1876 (Russell, 1956).

The new direction for the Morrow Plots enhanced their value for assessing the long-term impact on soil properties of farming practices then coming into use throughour Tllinois and the USA Corn Belt. The same rationale motivated a subsequent change during the 1960s, when oats was replaced by soybean in a 2-yr rotation with corn, whereas continuous corn was retained along with a legume-based rotation of corn, oats, and alfalfa (Medicago sativa L.) hay. The plots under these three rotations provide a valuable opportunity to evaluate the long-term effect on soil $\mathrm{C}$ sequestration after 40 to $50 \mathrm{yr}$ of repeatedly fertilizing corn with synthetic $N$ at a 1-, 2-, or 3-yr interval, particularly because surface and subsurface soil was sampled in the spring of 1955 before initiation of the new management strategy.

\section{Materials and Methods}

\section{Experimental Site}

The Morrow Plots occupy approximately 0.25 ha on the Urbana campus of the University of Illinois ( $40^{\circ} 06^{\prime} 17^{\prime \prime} \mathrm{N}$, $88^{\circ} 13^{\prime} 34^{\prime \prime}$ W). The soil type is mapped as Flanagan silt loam, a nearly level, somewhat poorly drained, dark-colored prairie soil classified as a fine, smectitic, mesic Aquic Argiudoll. To improve drainage, subsurface tile lines were installed in 1904.

Originally established in 1876 as a three-rotation experiment, the Morrow Plots were divided in 1904 with the introduction of manure, limestone, and rock phosphate or steamed bonemeal to the southern half of each plot. In 1955, the western half of the experimental area (designared in 1904 as NW and SW) was further divided into four subplots per rotation (Fig. 1) (NW was redesignared as NA and NB, and SW as SA and SB). Two of the subplots (NB and $\mathrm{SB}$ ) have since been fertilized with urea (168-224 $\mathrm{kg} \mathrm{N}$ $\mathrm{ha}^{-1}$ ) whenever cropped to corn, with or without limestone and commercial fertilizer (triple superphosphate and $\mathrm{KCl}$ ) that maintain a desired soil test level of $\mathrm{pH}, \mathrm{P}$, and $\mathrm{K}$. With the establishment of a corn-soybean rotation in 1967, a high NPK (HNPK) trearment was introduced to the $S A$ subplor within each rotation, which has subsequently been fertilized with $336 \mathrm{~kg} \mathrm{~N} \mathrm{ha}^{-1}$ (as urea) whenever com is grown. Planting rates for com have been increased periodically (from 20,000 or 30,000 to 69,000 plants ha $^{-1}$ ) for the NPK (NB and SB)- and HNPK (SA)-fertilized subplots but not for the unfertilized control (NA). Aboveground crop residues were originally removed from each plot but were incorporated beginning in 1955 for all B subplots except 5SB. Since 1967, this practice has been applied to all subplots, whereas the primary tillage practice since 1998 has been chisel instead of moldboard plowing. For additional details concerning the Morrow Plots and their management, the reader is referred to articles by Odell ec al. (1982, 1984), Darmody and Peck (1997), and Aref and Wander (1998).

\section{Soil Sampling and Analyses}

The work reported used surface $(0-15 \mathrm{~cm})$ samples of soil collected in 1904, 1933, 1955, 1967, 1980, and 2005 plus subsurface (15-30 and 30-46 cm) samples collected in 1955 and 2005.

Samples from 1904 to 1980 were obrained from an archival collection maintained by the University of Illinois in individually labeled air-ight glass containers. In the case of subplot $3 \mathrm{NW}$, an archival sample was unavailable for the $15-$ to $30-\mathrm{cm}$ depth in 1955 , so the corresponding sample was obtained from those collected in 1953.

The samples used in our work represent 9 of the 12 subplots that comprise the west half of the original experimental area, currently designated as NA, NB, and SA (see shaded areas in Fig. 1). Archived samples from 1904 to 1980 had been collected as a composite of at least five cores, whereas in 2005, triplicate samples were collected but not composited. In all cases, samples were air-dried and screened to $<2 \mathrm{~mm}$ soon after collection, and triplicate analyses were performed for total organic $\mathrm{C}$ by the dichromate oxidation technique of Mebius (1960). This technique was adopred to avoid $\mathrm{CO}_{3}{ }^{2-}$ interference in analyzing samples from limed subplots and was validated by comparing organic $\mathrm{C}$ measurements with and without the addition of $\mathrm{Cl}^{-}$at the highest concentration determined for NPK-fertilized subplots (530 $\mathrm{mg} \mathrm{k}^{-1}$ ) by titration with $\mathrm{AgNO}_{3}$ (Reitemeier, 1943).

Soil cores ( $3 \mathrm{~cm}$ diam.) for measuring bulk density (Blake and Hartge, 1986) were collected from the nine subplots studied to a depth of $46 \mathrm{~cm}$ after the 2005 growing season. The cores were oven-dried at 40 to $42^{\circ} \mathrm{C}$ to constant mass for estimating subplot-average bulk densities for depths of 0 to 15,15 to 30 , and 30 to $46 \mathrm{~cm}$.

A similar approach was adopred in estimaring baseline values for mass storage of soil organic $\mathrm{C}$ (SOC); however, bulk density was not measured in 1955, so pedotransfer functions were used following the same approach adopted in several previous investiga- 
tions (e.g., Adams, 1973; Chen et al., 1998; Post and Kwon, 2000; $\mathrm{De}$ Vos et al., 2005). Bulk density values for each of the upper two sampling depths were estimated from the corresponding 1955 subplot-average $S O C$ concentrations using linear regression functions calibrated with 2005 data $\left(r^{2}=0.63\right.$ for $0-15 \mathrm{~cm}$ and 0.64 for $15-30 \mathrm{~cm}$ ). Because of less variability in $2005 \mathrm{SOC}$ data for the 30- to 46-cm depth, the pedotransfer function for this depth in 1955 reverted statistically to a single bulk density $\left(1.45 \mathrm{Mg} \mathrm{m}^{-3}\right)$.

\section{Estimation of Carbon Input for 1955 to 2005}

A balance sheet was constructed for 1955 to 2005 by estimating the cumulative input of above- and belowground $C$ from annual yield records for each of the nine subplots studied. The return of residue $C$ was calculated using 1955 to 2003 yield records for the Morrow Plots, estimated yields for 2004 to 2005, and literature values for harvest index (HI), root-to-shoot ratio (RSR), and the percentage of $\mathrm{C}$ in stover and root residues. Yields for the most recent 2 yr were estimated for each treatment within a rotation by averaging data for 2001 to 2003 . The yield records used were expressed as dry tons acre ${ }^{-1}$ for alfalfa, or as bushels acre ${ }^{-1}$ at a market-standard moisture content of $155 \mathrm{~g} \mathrm{~kg}^{-1}(15.5 \%)$

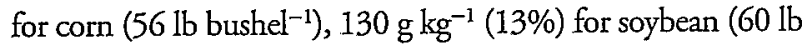
bushel-1), and $140 \mathrm{~g} \mathrm{~kg}^{-1}(14 \%)$ for oats (32 lb bushel-1).

A wide range of $H I$ and RSR estimates can be found in the literature, but with no consistent effect of hybrid, planting density, or $\mathrm{N}$ fertilization rate. To avoid overestimating residue $\mathrm{C}$ input for 1955 to 2005 , conservative values were used in our work with these parameters. Harvest index was estimated at 0.5 for corn (Leask and Daynard, 1973; Kiniry et al., 1997; Tollenaar et al., 2004), 0.4 for soybean (Prince et al., 2001), and 0.5 for oats (Prince et al., 2001). Each $H I$ value was used to estimate a corresponding total aboveground dry matter, whereas for alfalfa, the latter quantity was obrained directly from dry matter harvest yield. The following estimates were used for RSR: 1.0 for first-year alfalfa (Holechek, 1982) and 0.5 for corn, 0.6 for soybean, and 0.8 for oats (Prince et al., 2001; Johnson et al., 2006), assuming an approximately equal mass contribution for structural roots and rhizodeposition.

Literature-derived values for crop $\mathrm{C}$ composition (mass basis) were used to calculate total additions of residue $\mathrm{C}$. Using data published by Johnson et al. (2007), the aboveground residue (stover) was assumed to contain $437 \mathrm{~g} \mathrm{C} \mathrm{kg}^{-1}$ for corn and $454 \mathrm{~g} \mathrm{C} \mathrm{kg}^{-1}$ for soybean, with $343 \mathrm{~g} \mathrm{C} \mathrm{kg}^{-1}$ in root residues for corn, $467 \mathrm{~g}$ $\mathrm{C} \mathrm{kg}^{-1}$ for soybean, and $433 \mathrm{~g} \mathrm{C} \mathrm{kg}^{-1}$ for alfalfa. A single value of $440 \mathrm{~g} \mathrm{C} \mathrm{kg}^{-1}$ was used for oats (Izaurralde et al., 2001). Before 1967, aboveground residues were removed from subplots that subsequently received HNPK fertilization, and manure was applied to the corn crop ( $\sim 4.5 \mathrm{Mg} \mathrm{ha}^{-1}$ of dry weight as an annual average) as a means of returning nutrients removed in the residue. This manure, originating largely from the University's dairy operation, was assumed to contain $470 \mathrm{~g} \mathrm{C} \mathrm{kg}^{-1}$ (Liao et al., 2006).

\section{Statistical Analyses}

Data obtained for SOC and bulk density were analyzed statistically with PROC MIXED in SAS (SAS Institute, 2007), such that the 2005 data provided an appropriate variance to estimate standard error of the mean values obtained as five-core composites from 1904 to 1980 . Multiple comparison tests of SOC concentration and mass differences were performed with PROC MULTTEST in SAS using the step-down Bonferroni adjustment of $P$ values (Hochberg, 1988) for rigorous control of false negatives and false positives. Plow-layer SOC concentrations were evaluated over time using the Tukey-Kramer statistic.

\section{Results and Discussion}

\section{Nitrogen Fertilization and Soil Carbon Sequestration}

\section{Evidence from the Morrow Plots}

If the input of $\mathrm{C}$ and $\mathrm{N}$ promotes accumulation of SOM, then treatment effects should be apparent within the Morrow Plots, which vary in the amount and frequency of these inputs but not in soil type, climatic conditions, or tillage. These effects should be reflected by Table 1, which compares SOC concentrations for surface $(0-15 \mathrm{~cm})$ and subsurface (15-30 and 30-46 $\mathrm{cm})$ samples collected before and after five decades of continuous cropping with or without repeated NPK fertilization.

As opposed to the usual assumption, fertilization was of little, if any, benefit for soil C sequestration (Table 1). Rather, the only significant SOC changes detected were net losses, and these tended to be more extensive for the subsurface than the surface soil and more serious for the HNPK subplots than for the others studied. Both findings are consistent with evidence that the addition of $\mathrm{N}$ or $\mathrm{P}$ is more effective for stimulating mineralization of SOC in subsurface horizons, as compared with surface soil layers (e.g., Rovira and Vallejo, 1997; Soon and Arshad, 2002; Fierer et al., 2003; Mack et al., 2004). Unfortunately, current knowledge of SOC sequestration is based largely on data collected by sampling the surface soil but not the profile.

To better quantify how NPK fertilization has affected SOC storage in the Morrow Plots, C balance sheets were constructed for 1955 to 2005 using bulk density estimates to convert concentration data (Table 1) into an equivalent mass per hectare. The results, summarized by Table 2 for the plow layer $(0-15 \mathrm{~cm})$ and profile $(0-46 \mathrm{~cm})$, provide no convincing evidence of soil $\mathrm{C}$ sequestration in fertilized subplots despite the fact that $C$ inputs have benefited from a considerable increase in corn populations since 1955 (from 20,000 or 30,000 to 69,000 plants ha $^{-1}$ ). On the contrary, a decline usually occurred that was more intensive for the profile as a whole than for the plow layer.

The negative profile $\mathrm{C}$ balance observed in Table 2 for chemical-based $\mathrm{N}$ management is most reasonably interpreted as a net loss of the residue $C$ returned within the past 51 growing seasons accompanied by a substantial decline in the native $\mathrm{SOC}$ with atmospheric $\mathrm{CO}_{2}$ enrichment. This finding is of particular interest for continuous corn and the corn-soybean rotation and is consistent with data reported in Table 4 of Odell et al. $(1982,1984)$, although not with continued acceptance of the authors' interpretations.

A clearer picture emerges when changes in SOC are linked to the contrasting management systems imposed on the Morrow Plots during the past century. The course of such changes for 
Table 1. Effect of NPK fertilization on soil organic C concentrations measured for the Morrow Plots between 1955 and 2005.

\begin{tabular}{|c|c|c|c|c|c|c|}
\hline \multirow{3}{*}{ Rotationt } & \multirow{3}{*}{$\begin{array}{l}\text { Fertilizer } \\
\text { treatment‡ }\end{array}$} & \multirow{3}{*}{$\begin{array}{l}\text { Sampling } \\
\text { depth }\end{array}$} & \multicolumn{4}{|c|}{ Soil organic C\$ } \\
\hline & & & \multirow{2}{*}{1955} & \multicolumn{2}{|c|}{2005} & \multirow{2}{*}{$\begin{array}{c}\text { Net change in } \\
51 \text { yrg }\end{array}$} \\
\hline & & & & Mean & SD & \\
\hline & & $\mathrm{cm}$ & & & $\mathrm{g} \mathrm{kg}^{-1}$ & \\
\hline \multirow[t]{9}{*}{$C-C$} & None & $0-15$ & 15.3 & 15.3 & 1.5 & 0 \\
\hline & & $15-30$ & $14.2 \#$ & 13.0 & 0.8 & -1.2 \\
\hline & & $30-46$ & 11.8 & 13.2 & 1.4 & +1.4 \\
\hline & NPK & $0-15$ & 15.3 & 16.4 & 1.0 & +1.1 \\
\hline & & $15-30$ & $14.2 \#$ & 15.5 & 1.1 & +1.3 \\
\hline & & $30-46$ & 11.8 & 9.5 & 0.7 & $-2.3^{*}$ \\
\hline & HNPK & $0-15$ & 19.5 & 18.2 & 0.2 & $-1.3^{*}$ \\
\hline & & $15-30$ & 19.1 & 17.1 & 0.1 & $-2.0^{*}$ \\
\hline & & $30-46$ & 16.2 & 12.2 & 1.5 & $-4.0^{*}$ \\
\hline \multirow[t]{9}{*}{$C-O(S)$} & None & $0-15$ & 18.6 & 17.7 & 0.9 & -0.9 \\
\hline & & $15-30$ & 18.7 & 16.1 & 0.7 & $-2.6^{*}$ \\
\hline & & $30-46$ & 16.2 & 14.8 & 1.6 & $-1.4^{*}$ \\
\hline & NPK & $0-15$ & 18.6 & 18.7 & 0.8 & +0.1 \\
\hline & & $15-30$ & 18.7 & 17.2 & 0.4 & $-1.5^{*}$ \\
\hline & & $30-46$ & 16.2 & 14.3 & 1.9 & $-1.9^{*}$ \\
\hline & HNPK & $0-15$ & 22.9 & 18.1 & 0.6 & $-4.8^{*}$ \\
\hline & & $15-30$ & 20.4 & 16.4 & 0.8 & $-4.0^{*}$ \\
\hline & & $30-46$ & 15.2 & 11.5 & 1.7 & $-3.7^{*}$ \\
\hline \multirow[t]{9}{*}{$\mathrm{C}-\mathrm{O}-\mathrm{H}$} & None & $0-15$ & 20.7 & 21.0 & 0.7 & +0.3 \\
\hline & & $15-30$ & 19.4 & 18.3 & 0.4 & $-1.1^{*}$ \\
\hline & & $30-46$ & 15.8 & 11.1 & 1.1 & $-4.7^{*}$ \\
\hline & NPK & $0-15$ & 20.7 & 21.2 & 0.7 & +0.5 \\
\hline & & $15-30$ & 19.4 & 19.8 & 0.9 & +0.4 \\
\hline & & $30-46$ & 15.8 & 13.6 & 1.9 & -2.2 \\
\hline & HNPK & $0-15$ & 27.7 & 24.4 & 2.0 & -3.3 \\
\hline & & $15-30$ & 25.0 & 20.5 & 1.4 & $-4.5^{*}$ \\
\hline & & $30-46$ & 18.9 & 13.0 & 2.7 & $-5.9^{*}$ \\
\hline
\end{tabular}

* Significant at $\alpha=0.05$ by the step-down Bonferroni procedure. † C, corn; O, oats; S, soybean; $H$, alfalfa hay. Since 1967 , the two-crop rotation has involved soybean instead of oats.

\# NPK, NPK fertilization (168 [1955-1966] or 224 [since 1967] kg N ha-1 for corn, $28 \mathrm{~kg} \mathrm{~N}$ ha-1 for oats) with no amendment before 1955; HNPK, high NPK fertilization ( $336 \mathrm{~kg} \mathrm{~N} \mathrm{ha-1}$ for corn, $28 \mathrm{~kg} \mathrm{~N}$ ha-i for oats) since 1967, after manure, limestone, and rock phosphate application from 1904 to 1966.

$\S$ Determined by the method of Mebius (1960). Standard deviation averaged $0.2 \mathrm{~g} \mathrm{~kg}^{-1}$ for triplicate determinations of 1955 samples. I Obtained by difference.

\# Analyses were performed on a sample collected in 1953, representing the same management practiced in 1955.

the plow layer is shown in Fig. 2 for subplots currently receiving NPK ferrilization, with (solid circles) or without (open circles) a history of manure, limestone, and rock phosphate usage. Before synthetic $N$ fertilization, crop rotations with corn populations of 20,000 or 30,000 plants $\mathrm{h}^{-1}$ showed considerable promise for sequestering soil $\mathrm{C}$ if accompanied by manuring that compensated for aboveground residue removal. The first decade of commercial fertilization brought a minor increase in soil $\mathrm{C}$ for previously unamended subplots, but this was followed by a decline despite dramatic escalation in the return of above- and belowground residues as corn populations were increased progressively to 69,000 plants ha ${ }^{-1}$ by 2003 . Since 1980 , residue inputs to fertilized Morrow Plots under continuous corn or a corn-soybean rotation have generated at least $5.4 \mathrm{MgC} \mathrm{ha}{ }^{-1} \mathrm{yr}^{-1}$, proposed by
Larson et al. (1972) as a minimal requirement for SOC storage with conventional tillage. Yet Fig. 2 provides no evidence of an upward trend in SOC concentration during this period, which is consistent with several other studies conducted within the past 25 yr (e.g., Wander et al., 1994; Lesoing and Doran, 1997; Pikul et al., 2001; Wilts et al., 2004; Olson et al., 2005; Varvel, 2006).

The loss of SOC was more serious with the HNPK than the NPK trearment despite a similar residue $C$ inpur as estimated in Table 2. This difference, which was clearly evident for the plow layer but even more dramatic for the profile, occurred despite fertilizer N inputs since 1967 that exceeded those of the NPK treatment, when averaged on an annual basis, by $112 \mathrm{~kg} \mathrm{ha}^{-1}$ for continuous corn, $56 \mathrm{~kg} \mathrm{ha}^{-1}$ for the corn-soybean rotation, and $37 \mathrm{~kg} \mathrm{ha}^{-1}$ for the corn-oats-hay rotarion. According to Table 1, the HNPK treatment substantially increased surface and subsurface $\mathrm{C}$ losses as compared with the NPK treatment.

Among the three HNPK subplots, the decline in SOC was much more extensive for the two rotations than for continuous corn, despite a lower frequency of $\mathrm{N}$ fertilization. This finding demonstrates the value of a greater input of highly carbonaceous corn residue for reducing microbial use of SOC and emphasizes the importance of fertilizer $\mathrm{N}$ management if corn stover is to be harvested for bioenergy production. Special attention is also warranted for the corn-soybean rotation that now dominates the USA Corn Belt, in that $\mathrm{C}$ accumularion from manuring before introduction of the HNPK trearment had disappeared within the plow layer by 2005 (Fig. 2), with substantially greater profile $C$ depletion than for the NPK subplor in this rotarion (Table 2). This finding is consistent with previous reports of SOC decline when soils are managed for corn and soybean production (Varvel, 1994, 2006; Peters et al., 1997; Pikul et al., 2001; Olson et al., 2005).

The foregoing observations fully support the value of $\mathrm{N}$ fertilization at either rate studied for increasing biomass production but not for sequestering SOC. This disparity would be expected if fertilizer $N$ enhances the activities of heterotrophic soil microorganisms in using $\mathrm{C}$ derived from crop residues or SOM. Such an effect was recognized long before the modern era of synthetic $\mathrm{N}$ fertilizers (e.g., Starkey, 1924; White, 1927; Waksman and Tenney, 1928) and has been verified more recently in several laboratory and field investigations (Gusser, 1970; Tóth, 1977; Reinertsen et al., 1984; Janzen and Kucey, 1988; Green et al., 1995; Vigil and Sparks, 1995; Soon and Arshad, 2002; Fierer et al., 2003; Conde et al., 2005).

\section{Evidence from Other Studies}

If $N$ fertilization can have a negative effect on soil $C$ sequestration, the same trend observed for the Morrow Plots should be readily evident from dara collected in field studies elsewhere. Such evidence is common in the scientific literature but has seldom been acknowledged, perhaps because $\mathrm{N}$ fertilizer practices have been predicared largely on short-term economic gain rather than longterm sustainability. Within the USA Corn Belt, fertilizer $N$ has often been found to increase biomass production while being of little benefit to soil $C$ sequestration, according to studies conducted with various tillage systems in Indiana (Barber, 1979), Iowa (Russell et al., 2005), Kansas (Dodge and Jones, 1948), Kentucky (Blevins et 
Table 2. Effect of NPK fertilization on organic C storage in the Morrow Plots between 1955 and 2005.

\begin{tabular}{|c|c|c|c|c|c|c|c|c|c|}
\hline \multirow[b]{3}{*}{ Rotationt } & \multirow{3}{*}{$\begin{array}{l}\text { Fertilizer } \\
\text { treatmentt }\end{array}$} & \multirow{3}{*}{$\begin{array}{c}\text { Fertilizer } N \\
\text { input }\end{array}$} & \multirow{3}{*}{$\begin{array}{c}\text { Residue C } \\
\text { input } \neq\end{array}$} & \multicolumn{4}{|c|}{ Soil organic C§ } & \multirow{2}{*}{\multicolumn{2}{|c|}{$\begin{array}{l}\text { Net change in soil } C \\
\text { storage after } 51 \mathrm{yr} 7\end{array}$}} \\
\hline & & & & \multicolumn{2}{|c|}{$0-15 \mathrm{~cm}$ (plow layer) } & \multicolumn{2}{|c|}{$0-46 \mathrm{~cm}$ (profile) } & & \\
\hline & & & & 1955 & 2005 & 1955 & 2005 & $0-15 \mathrm{~cm}$ & $0-46 \mathrm{~cm}$ \\
\hline & & & & & $-\mathrm{Mg}$ & & & & \\
\hline \multirow[t]{3}{*}{$C-C$} & None & 0 & 81 & 34.7 & 34.0 & 94.3 & 98.0 & -0.7 & +3.7 \\
\hline & NPK & 10.8 & 276 & 34.7 & 36.9 & 94.3 & 94.0 & +2.2 & -0.3 \\
\hline & HNPK & 13.1 & 277 & 42.0 & 41.7 & 119.6 & 108.9 & -0.3 & $-10.7^{*}$ \\
\hline \multirow[t]{3}{*}{$\mathrm{C}-\mathrm{O}(\mathrm{S})$} & None & 0 & 135 & 40.5 & 40.4 & 117.5 & 111.9 & -0.1 & -5.6 \\
\hline & NPK & 5.7 & 248 & 40.5 & 40.2 & 117.5 & 112.3 & -0.3 & -5.2 \\
\hline & HNPK & 6.7 & 253 & 47.3 & 40.1 & 124.6 & 102.7 & $-7.2^{*}$ & $-21.9^{*}$ \\
\hline \multirow[t]{3}{*}{$\mathrm{C}-\mathrm{O}-\mathrm{H}$} & None & 0 & 92 & 43.9 & 44.5 & 121.2 & 109.8 & +0.6 & $-11.4^{*}$ \\
\hline & NPK & 4.1 & 203 & 43.9 & 44.9 & 121.2 & 116.4 & +1.0 & -4.8 \\
\hline & HNPK & 4.7 & 221 & 53.7 & 50.3 & 145.0 & 121.8 & -3.4 & $-23.2^{*}$ \\
\hline
\end{tabular}

ॠ Significant at $\alpha=0.05$ by the step-down Bonferroni procedure.

$+\mathrm{C}$, corn; $\mathrm{O}$, oats; $\mathrm{S}$, soybean; $\mathrm{H}$, alfalfa hay. Since 1967 , the two-crop rotation has involved soybean instead of oats. NPK, NPK fertilization (168 [19551966 ] or 224 [since 1967] kg N ha-1 for corn, $28 \mathrm{~kg} \mathrm{~N} \mathrm{ha}^{-1}$ for oats) with no amendment before 1955; HNPK, high NPK fertilization (336 kg N ha ${ }^{-1}$ for corn, $28 \mathrm{~kg} \mathrm{~N} \mathrm{ha}^{-1}$ for oats) since 1967, after manure, limestone, and rock phosphate application from 1904 to 1966.

₹ Estimated from yield records using published values for $H I, R S R$, and stover and root C concentrations (for details, see Materials and Methods). Values for HNPK include manure C inputs estimated for 1955-1966.

$\$$ Organic $C$ data reported in Table 1 were converted to soil $C$ mass per hectare using bulk density data collected after the 2005 growing season.

I Obtained by difference.

al., 1983), Michigan (Vitosh et al., 1997), Minnesota (Reicosky et al., 2002), Missouri (Smith, 1942), Nebraska (Lesoing and Doran, 1997), North Dakota (Black and Tanaka, 1997), South Dakota (Pikul et al., 2001), and Wisconsin (Motavalli et al., 1992). The same trend has been documented more widely not only for corn (Gusser, 1970; Bloom et al., 1982; Huggins and Fuchs, 1997; Peters et al., 1997; Vanotti et al., 1997; Liang et al., 1998; Clapp et al., 2000; Brye et al., 2002; Wilts et al., 2004) but also for wheat (Triticum aestivum L.) (Dyer, 1902; White, 1927; Rasmussen et al., 1980; Campbell et al., 1991; Jenkinson, 1991; Campbell and Zentner, 1993, 1997; Rasmussen and Parton, 1994; Dalal et al., 1995; Nyborg et al., 1995; Rasmussen and Smiley, 1997; Potter et al., 1998; Izaurralde et al., 2001; Halvorson et al., 2002; Follett et al., 2005; Machado et al., 2006), barley (Hordeum vulgare L.) (Jenkinson and Johnston, 1977; Johnston, 1997; Machado et al., 2006), rice (Oryza sativa L.) (Lal, 1986), cotton (Gossypium birsutum L.) (Cope et.al., 1958; Sainju et al., 2005), various mixed cropping systems (Draycott et al., 1978; Christensen and Johnston, 1997; Potter et al., 1998; Sainju et al., 2002, 2006), and pine plantations (Harding and Jokela, 1994; Leggett and Kelting, 2006).

In contrast to the foregoing evidence, reports that $\mathrm{N}$ fertilization can increase SOC sequestration are by no means uncommon in the literature. Typically, such findings do not meet the fundamental requirement for baseline data in assessing SOC changes over time (e.g., Jenkinson, 1991; Campbell et al., 2000; VandenBygaart and Angers, 2006) but rely on a comparison relative to an unfertilized control (e.g., Larson et al., 1972; Havlin et al., 1990; Malhi et al., 1997, 2002; Solberg et al., 1997; Dormaar and Carefoot, 1998; Raun et al., 1998; Nyborg et al., 1999; Liebig et al., 2002). The same erroneous conclusion could be reached if this approach were applied to the 2005 data reported in Table 2 because soil $C$ content was often greater for fertilized than unfertilized subplots. Misinterpretations can also arise when (i) inorganic fertilizer inputs are confounded by current or previous manure practices (e.g., Liang and MacKenzie, 1992; Darmody and Peck, 1997), (ii)
SOC data represent only a very limited depth of surface soil (e.g., Varvel, 1994; Solberg et al., 1997), or (iii) the study period is in-

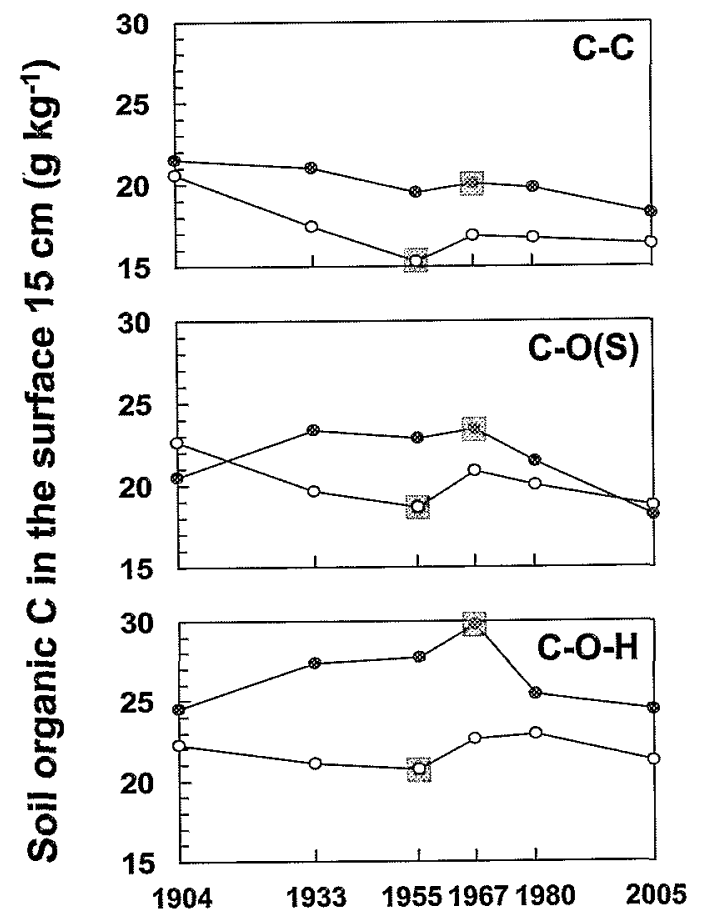

Fig. 2. A century of changes in organic $C$ concentrations for the plow layer in Morrow Plots cropped to continuous corn $[\mathrm{C}-\mathrm{C}]$, a corn-oats (1876-1966) or corn-soybean (since 1967) rotation [C-O(S)], or a corn-oats-alfalfa hay rotation [C-O-H]. Open circles represent NB subplots with fertilizer and aboveground residue inputs beginning in 1955 . Solid circles represent $S A$ subplots with manure, limestone, and rock phosphate inputs before 1967, subsequently replaced by high NPK fertilization and aboveground residue return. Shaded boxes indicate the introduction of NPK fertilization. Triplicate analyses for organic $C$ were performed by the method of Mebius (1960). Using the Tukey-Kramer statistic at $\alpha=0.05$, significant differences must exceed $2.5 \mathrm{~g} \mathrm{~kg}^{-1}$ within a time series and $2.9 \mathrm{~g} \mathrm{~kg}^{-1}$ for comparison of individual values within a chart. 
adequate for detecting SOC changes (e.g., Liang and MacKenzie, 1992; Varvel, 1994; Dormaar and Carefoot, 1998). Moreover, $N$ fertilization can have a positive effect on SOC sequestration if acidity generated during $\mathrm{NH}_{4}^{+}$oxidation is not controlled, thereby impeding $\mathrm{C}$ decomposition (e.g., Fog, 1988; McAndrew and Malhi, 1992; Ismail et al., 1994; Malhi et al., 1997; Vanotri et al., 1997).

Among field studies involving synthetic $\mathrm{N}$ fertilization and reporting baseline data, the usual finding has been a decrease over time in SOC storage. This is apparent from Table 3, which summarizes relevant data sets representing a wide variety of cropping systems, tillage practices, and geographic regions. The major exceptions occurred in experiments with continuous corn or wheat at Sanborn Field in Missouri reported by Buyanovsky and Wagner (1998). In their work, sequestration was more extensive with no-till than with conventional tillage, as is consistent with average estimates of at least $0.5 \mathrm{MgC} \mathrm{ha}^{-1} \mathrm{yr}^{-1}$ after conversion of conventional tillage to no-till (e.g., Lal et al., 1999; West and Post, 2002). Such estimates may be questioned in view of the SOC decreases observed for no-till when sampling has been done to a depth of at least $30 \mathrm{~cm}$ (see Table 3), which was identified as a major concern in a recent commentary by Baker et al. (2007). Also in doubt is the feasibility of using no-till residues as a bioenergy feedstock for ethanol production, a concept currently being advocated in preference to other tillage systems that are less effective for erosion control (Graham et al., 2007). This strategy may be a source of short-term economic gain for producers, but there are implications for long-term soil deterioration because residue removal would accelerate SOC oxidation, particularly with heavy $\mathrm{N}$ fertilization. The likely impact is evident from Table 3; SOC losses were of greater magnitude when corn was grown for silage as opposed to grain production.

The Yield-Based Paradigm

With growing dependence on synthetic $N$ fertilizers during the past $60 \mathrm{yr}$, the assertion has often been made that these inputs are a positive factor in maintaining or increasing SOM because higher yields enhance the input of crop residues (e.g., Parker, 1946; Lee and Bray, 1949; Lyon et al., 1952; Melsted, 1954; Tisdale and Nelson, 1956; Aldrich, 1980; Odell et al., 1984; Tate, 1987; Reetz et al., 1989; Mitchell et al., 1991; Lal et al., 1999; Wolf, 1999; Brady and Weil, 2002; Havlin et al., 2005; Dobermann et al., 2005). Yield-based recommendations in common use for corn production during the past three decades rely on the premise that fertilization, rather than indigenous soil $\mathrm{N}$ availability, is the major source for crop uptake. Yet this premise is inconsistent with considerable evidence from ${ }^{15} \mathrm{~N}$-tracer investigations that plant uptake is generally more extensive for soil than ferrilizer $\mathrm{N}$ when corn is grown to maturity with typical or even excessive fertilization (e.g., IAEA, 1970; Chichester and Smith, 1978; Bigeriego et al., 1979; Gerwing et al., 1979; Olson, 1980; Kitur et al., 1984; Blackmer and Sanchez, 1988; Timmons and Cruse, 1990; Balabane and Balesdent, 1992; Reddy and Reddy, 1993; Torbert et al., 1993; Jokela and Randall, 1997; Tran et al., 1997; Omay et al., 1998; Stevens et al., 2005). Such evidence is substantiated by on-farm $\mathrm{N}$-response studies because there is often a limited difference, if any, berween fertilized and unfertilized (check) plot yields (e.g., IAEA, 1970; Bundy and Malone, 1988; Blackmer et al., 1989, 1992; Fox et al., 1989; Meisinger et al., 1992; Schmitt and Randall, 1994; Brown, 1996; Khan et al., 2001; Mulvaney et al., 2001, 2006; Lory and Scharf, 2003), nor is there a meaningful correlation $\left(r^{2}<0.02\right)$ between economically optimum yield and $N$ rate (Khan et al., 2001; Lory and Scharf, 2003; Mulvaney et al., 2006). Regardless, yield-based recommendations have remained an important aspect of current fertilizer $\mathrm{N}$ management for corn production in and beyond the USA Corn Belt (e.g., Hoeft and Peck, 2002; McFarland et al., 2005). In $102 \mathrm{~N}$-response experiments conducted on farmer fields in Illinois, Mulvaney et al. (2006) found that these recommendations averaged $154 \mathrm{~kg} \mathrm{ha}^{-1}$ as compared with a mean value of $90 \mathrm{~kg} \mathrm{ha}^{-1}$ for the economically optimum $N$ rate.

\section{Importance of Nitrogen Fertilizer Management for Soil Carbon Sequestration}

\section{Excessive Fertilization with Yield-Based Nitrogen Recommendations}

The dramatic increase in corn yields for NPK-fertilized Morrow Plots is closely correlated $\left(r=0.89^{* * *}\right)$ with Illinois statewide average dara (Aref and Wander, 1998). Both can be attributed to several interacting factors in addition to $\mathrm{N}$ fertilization, particularly improved hybrids, herbicide usage, and high plant populations (Cardwell, 1982). With yieldbased $N$ management, all of these factors promote consumption of $\mathrm{N}$ fertilizers, which have often been advocated as insurance against the most common nurrient limitation. So convincing has this rationale been that in the state of lllinois the input of fertilizer $\mathrm{N}$ had surpassed grain $\mathrm{N}$ removal by 1966 , and this disparity has been a common occurrence in subsequent decades, providing a surplus of almost $50 \%$ on average (Fig. 3). The extent of overfertilization has been far more serious because grain $\mathrm{N}$ originates largely from the soil rather than fertilizer according to numerous ${ }^{15} \mathrm{~N}$-tracer investigations cited previously, and particularly so in the case of highly productive Mollisols. The finding that SOC storage tends to be limited for such soils (e.g., Campbell et al., 1997; Janzen et al., 1997) is consistent with the dramatic SOC decline that occurred when the HNPK treatment was applied to the most fertile soils in the Morrow Plots (see Tables 1 and 2 and Fig. 2), and with a recent series of onfarm studies by VandenBygaart et al. (2002) documenting a net loss of SOC for high-yielding no-till sites under a cornsoybean-wheat rotation in eastern Canada.

More widespread use of excessive fertilizer $\mathrm{N}$ is documented for the USA Corn Belt by Table 4, which estimates the magnitude and cost (at $\$ 0.388 \mathrm{~kg}^{-1} \mathrm{~N}$ ) of overfertilization and also estimates $\mathrm{CO}_{2}$ emissions associated with manufacture and transport of the excess $\mathrm{N}\left(1.2 \mathrm{MgC} \mathrm{Mg}^{-1} \mathrm{~N}\right)$. A clear pattern exists: $N$ application exceeds grain $N$ removal, except in the case of Wisconsin, where fertilizer $\mathrm{N}$ consumption is reduced by exrensive use of forage legumes and manure. The same pattern applies when corn was grown on the Morrow Plots, in that fertilizer $\mathrm{N}$ inputs exceeded grain $\mathrm{N}$ removal by 
Table 3. Changes reported in soil organic $\mathrm{C}$ storage relative to baseline data, from cropping experiments with $\mathrm{N}$ fertilization. $\dagger$

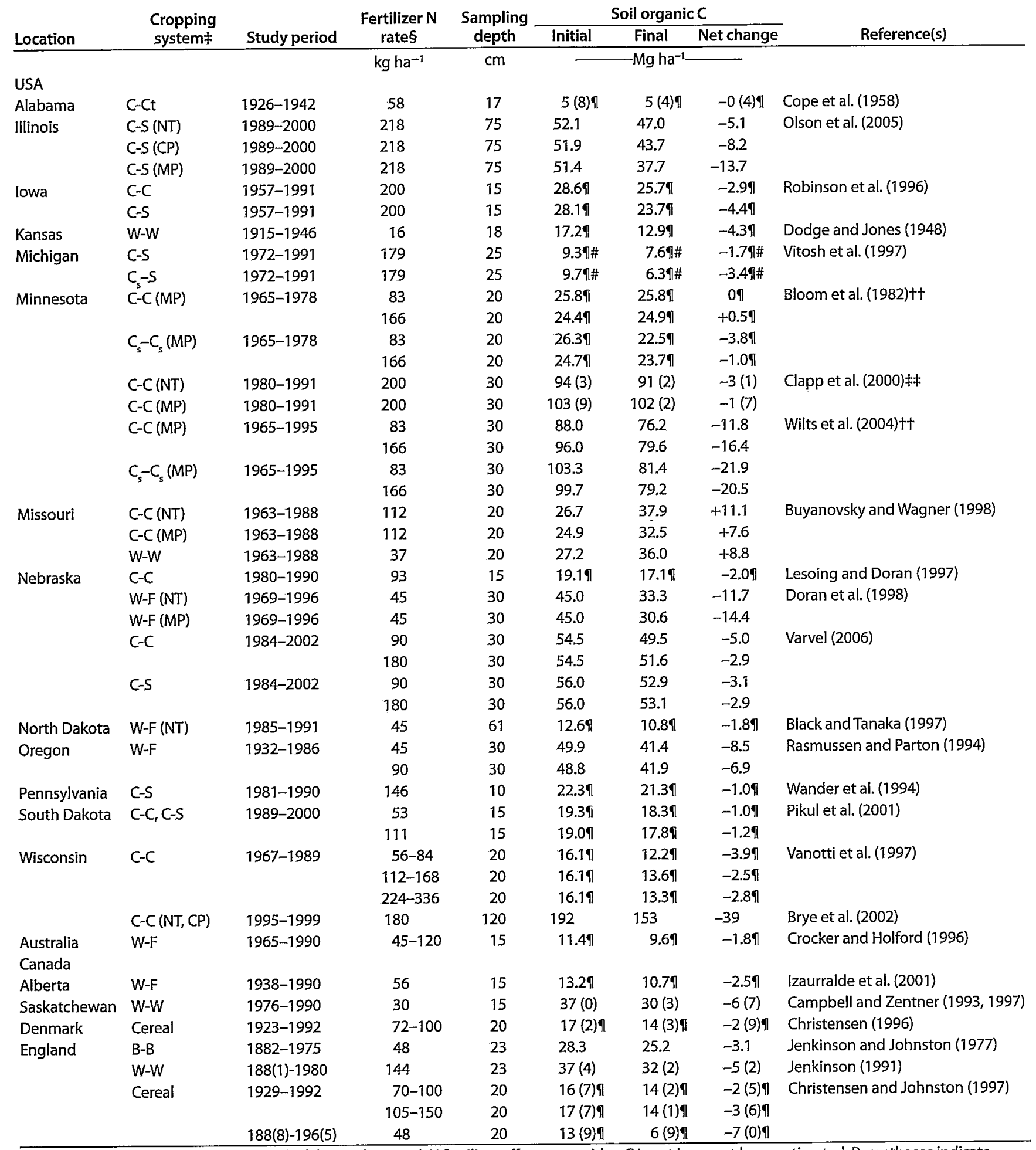

f Owing to a lack of yield data in several of the studies cited, $\mathrm{N}$ fertilizer effects on residue $\mathrm{C}$ input have not been estimated. Parentheses indicate uncertainty in estimating data reported in figures.

$\neq C$, corn; $C t$, cotton; $S$, soybean; NT, no-tillage; $C$, chisel plow; MP, moldboard plow; W, wheat; $C s$, corn harvested for silage; $F$, fallow; $B$, barley.

$\S$ For rotations, the $\mathrm{N}$ rate reported is for the first crop listed (both crops for $\mathrm{C}-\mathrm{Ct}$ ).

IValues expressed as $\mathrm{g} \mathrm{kg}^{-1}$.

\# Values reported as a mean from two treatments differing in $P$ and $K$ fertilization.

f The same site was studied by Bloom et al. (1982) and by Wilts et al. (2004).

+ A. marked increase in soil organic C, reported for 0-15 cm with no-till between 1991 and 1993, was not reflected in the authors' discussion or conclusions, and hence is not represented by the values cited. By including 1993 , the net change is $+12.8 \mathrm{Mg} \mathrm{ha}^{-1}$ for NT and $-7.3 \mathrm{Mg} \mathrm{ha}^{-1}$ for MP. 


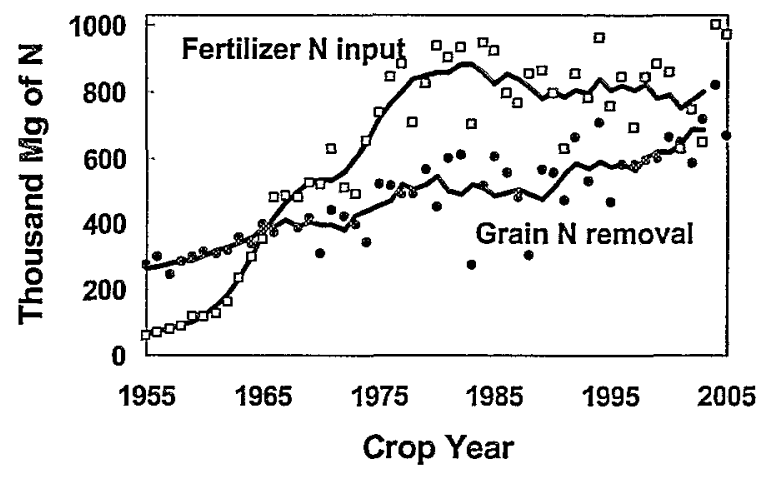

Fig. 3. Illinois data for fertilizer N input (open square) (Brown, 1955-1963; Illinois Department of Agriculture, 1964-2005) and grain $\mathrm{N}$ removal (solid circle) in corn, wheat, oats, barley, and rye (Secale cereale L.), calculated as a 5-yr moving average. Grain $\mathrm{N}$ removal was estimated using on-line data (USDA, 2007) for hectares harvested and mean yield $\left(\mathrm{Mg} \mathrm{ha}^{-1}\right)$, and grain $\mathrm{N}$ concentration calculated from textbook values for crude protein (Martin et al., 1976), assuming 175 (wheat) or 160 (all other crops) $\mathrm{g} \mathrm{N} \mathrm{kg}^{-7}$ protein.

a factor of 1.6 to 2.0 for the NPK treatment, whereas a 2.4to 2.9-fold difference existed for the HNPK treatment.

Further examination of Table 4 reveals a distinct difference between the two adjacent states that rank highest in corn production, in that Iowa produces more grain with lower fertilizer $\mathrm{N}$ usage as compared with Illinois. This difference, reflected in a sixfold reduction in the cost and $\mathrm{C}$ emission of excess fertil-

Table 4. Relationship of annual $\mathrm{N}$ fertilization to $\mathrm{N}$ removal in corn grain during 1994-2001 for 12 states that largely comprise the USA Corn Belt.

\begin{tabular}{|c|c|c|c|c|c|}
\hline \multirow[b]{2}{*}{ State } & \multirow{2}{*}{$\begin{array}{c}\text { Fertilizer } N \\
\text { input } f\end{array}$} & \multirow{2}{*}{$\underset{\text { removal }}{\text { Grain } \mathbf{N}}$} & \multicolumn{3}{|c|}{ Excess fertilizer $\mathbf{N}$} \\
\hline & & & Magnitudes & Cost 1 & Cemission \\
\hline & & $-\mathrm{Mg} \times 10^{3}$ & 3 & $\$ \times 10^{5}$ & $\mathrm{Mg} \times 10^{3}$ \\
\hline Illinois & 768.6 & 569.1 & 199.5 & 77.4 & 239.4 \\
\hline Indiana & 377.2 & 285.0 & 92.2 & 35.8 & 110.6 \\
\hline lowa & 671.7 & 641.8 & 29.9 & 11.6 & 35.9 \\
\hline Kansast† & 198.9 & 140.8 & 58.1 & 22.5 & 69.7 \\
\hline Kentuckytt & 92.1 & 51.4 & 40.7 & 15.8 & 48.8 \\
\hline Michigan & 120.9 & 90.1 & 30.8 & 12.0 & 37.0 \\
\hline Minnesota & 346.5 & 337.0 & 9.5 & 3.7 & 11.4 \\
\hline Missouri & 178.2 & 112.2 & 66.0 & 25.6 & 79.2 \\
\hline Nebraska & 527.4 & 418.6 & 108.8 & 42.2 & 130.6 \\
\hline Ohio & 246.0 & 161.2 & 84.8 & 33.0 & 101.8 \\
\hline South Dakota & 146.1 & 134.7 & 11.4 & 4.4 & 13.7 \\
\hline Wisconsin & 139.1 & 142.4 & -3.3 & -1.2 & -4.0 \\
\hline
\end{tabular}

t As reported in USDA (2007).

\# Estimated as the product of total corn production for the area harvested (USDA ${ }_{t}$ 2007) and grain N concentration calculated as $93 \mathrm{~g}$ crude protein $\mathrm{kg}^{-1}$ (Martin et al., 1976) divided by 6.25 .

$\S$ Obtained as the difference, fertilizer $N$ input - grain $N$ removal. Values reported have not been adjusted to account for corn uptake of $N$ derived from soil or previous crop residue nor to account for non-corn uptake of residual fertilizer $\mathrm{N}$.

1. Calculated using the mean price of anhydrous $\mathrm{NH}_{3}$ for 1995-2001 (USDA, 2007).

\# Estimated by assuming a value of $1.2 \mathrm{Mg} \mathrm{C} \mathrm{Mg}^{-1} \mathrm{~N}$ (Schlesinger, 2000) for estimation of $\mathrm{CO}_{2}$ emissions during manufacture and transport of excess fertilizer $N$.

t† Data reported as a mean of 6 crop-years $(1995,1996,1998,1999$, $2000,2001)$ rather than for the entire 8 -yr period specified. izer $N$, may be attributed to education programs implemented in Iowa during the 1990s that advocated lower $N$ rates with spring soil testing for $\mathrm{NO}_{3}$ - (Blackmer et al., 1997).

\section{Potential Value of Soil-Based Nitrogen Management}

If the potential benefits of $\mathrm{N}$ fertilizers are to be fully realized, applications must be adequate but not excessive, so as to maximize the economic profitability of crop production while minimizing microbial oxidation of residue $\mathrm{C}$ and native SOC. This strategy merits serious consideration because soils hold more than twice as much $\mathrm{C}$ as the atmosphere, and even a minor change in terrestrial $\mathrm{CO}_{2}$ balance could have a significant global impact (Powlson, 2005). Moreover, fertilization beyond crop $\mathrm{N}$ requirement contributes to anthropogenic production of $\mathrm{N}_{2} \mathrm{O}$, a potent greenhouse gas that has generated concern because of adverse implications for stratospheric ozone (McSwiney and Robertson, 2005). There are other environmental incentives because excessive fertilizer $\mathrm{N}$ promotes $\mathrm{NO}_{3}^{-}$pollution of ground and surface waters.

A substantial reduction in fertilizer $N$ usage can be achieved by accounting for the soil's capacity to supply plant-available $\mathrm{N}$ through mineralizarion. Soil $\mathrm{NO}_{3}{ }^{-}$testing has been used with some success to identify sites where corn is nonresponsive to $N$ fertilization (Magdoff et al., 1984; Bundy and Malone, 1988; Blackmer et al., 1989, 1992; Fox et al., 1989; Roth and Fox, 1990; Meisinger et al., 1992; Bundy and Meisinger, 1994; Schmitt and Randall, 1994), although test values are prone to extensive fluctuations in time and space due to numerous $\mathrm{N}$-cycle processes that affect soil $\mathrm{NO}_{3}{ }^{-}$concentrations. Recent work suggests that nonresponsive sites can be identified with greater reliability on the basis of allkalilabile organic $N$, a less dynamic form of soil $N$ that can be estimated with the Illinois soil $N$ test (ISNT) (Khan et al., 2001). In 102 on-farm N-response experiments, the ISNT was significantly related to crop $N$ requirement and was the most powerful predictor of error in yield-based $\mathrm{N}$ recommendations (Mulvaney et al., 2006). There is growing evidence from $N$-response evaluations that the ISNT can be used successfully for manure and fertilizer $\mathrm{N}$ management (Klapwyck and Ketterings, 2006; Klapwyck et al., 2006; Ruffo et al., 2006; Williams et al., 2007), although misinterpretarions have occurred when other factors were neglected that affect crop $N$ uptake or soil $N$ availability, such as plant population, residue $\mathrm{C}$ input, soil acidity, or a deficiency of $\mathrm{P}$ or $\mathrm{K}$.

\section{Conclusion}

A half century of synthetic $N$ fertilization has played a crucial role in expanding worldwide grain production, but there has been a hidden cost to the soil resource: a net loss of native SOC and the residue $C$ inputs. This cost has been exacerbated by the widespread use of yield-based systems for fertilizer $\mathrm{N}$ management, which are advocated for the sake of short-term economic gain rather than long-term sustainability. Fertilization beyond crop $N$ requirements could be reduced substantially by a shift from yield- to soil-based $\mathrm{N}$ management, ideally implemented on a site-specific basis. This strategy may be of value for reversing the ongoing organic matter decline of arable soils, but several decades will likely be necessary before any such benefit can realistically be expected to emerge. In the meantime, caution is warranted in 
avoiding excessive $\mathrm{N}$ fertilization, and especially with the current trend toward the use of crop residues for bioenergy production.

\section{Acknowledgments}

We thank Dr. T.R. Peck (now deceased) for preserving and archiving soil samples collected from the Morrow Plots, Dr. M.M. Wander for providing access to this collection of soil samples, Dr. S. Aref for assistance with the statistical analyses reported, and all whose efforts have contributed toward continuous cropping at this site for more than 130 years. Appreciation is also expressed to several anonymous reviewers for their valuable insight and suggestions.

\section{References}

Adams, W.A. 1973. The effect of organic matter on the bulk and true densities of some uncultivated Podzolic soils. J. Soil Sci. 24:10-17.

Aldrich, S.R. 1980. Nitrogen in relation to food, environment, and energy. Spec. Publ. 61. Univ. of Illinois, Urbana-Champaign, IL.

Aref, S., and M.M. Wander. 1998. Long-term trends of corn yield and soil organic matter in different crop sequences and soil ferrility treatments on the Morrow Plots. Adv. Agron. 62:153-197.

Baker, J.M., T.E. Ochsner, R.T. Venterea, and T.J. Griffis. 2007. Tillage and soil carbon sequestration: What do we really know? Agric. Ecosyst. Environ. 118:1-5.

Balabane, M., and J. Balesdent. 1992. Input of fertilizer-derived labelled N to soil organic matter during a growing season of maize in the field. Soil Biol. Biochem. 24:89-96.

Barber, S.A. 1979. Corn residue management and soil organic matter. Agron. J. 71:625-627.

Bigeriego, M., R.D. Hauck, and R.A. Olson. 1979. Uptake, translocation, and utilization of ${ }^{15} \mathrm{~N}$-depleted fertilizer in irrigated corn. Soil Sci. Soc. Am. J. 43:528-533.

Black, A.L., and D.L. Tanaka. 1997. A conservation tillage-cropping systems study in the Northern Great Plains of the United States. p. 335-342. In E.A. Paul et al. (ed.) Soil organic matter in temperate agroecosystems: Long-term experiments in North America. CRC Press, Boca Raton, FL.

Blackmer, A.M., T.E Morris, and G.D. Binford. 1992. Predicting N fertilizer needs for corn in humid regions: Advances in Iowa. p. 57-72. In B.R. Bock and K.R. Kelley (ed.) Predicting N fertilizer needs for corn in humid regions. Bull. Y-226. Tennessee Valley Authority, Muscle Shoals, AL.

Blackmer, A.M., D. Pottker, M.E. Cerrato, and J. Webb. 1989. Correlations between soil nitrate concentrations in late spring and corn fields in lowa. J. Prod. Agric. 2:103-109.

Blackmer, A.M., and C.A. Sanchez. 1988. Response of corn to nitrogen15-labeled anhydrous ammonia with and without nitrapyrin in Iowa. Agron. J. 80:95-102.

Blackmer, A.M., R.D. Voss, and A.P. Mallarino. 1997. Nitrogen fertilizer recommendations for corn in Iowa. Pm-1714. Iowa State Univ, Ames, IA.

Blake, G.R., and K.H. Hartge. 1986. Bulk density. p. 363-375. In A. Klute (ed.) Methods of soil analysis. Part 1. Agron. Monogr. 9, 2nd ed. ASA and SSSA, Madison, WI.

Blevins, R.L., G.W. Thomas, M.S. Smith, W.W. Frye, and P.L. Cornelius. 1983. Changes in soil properties after 10 years continuous non-tilled and conventionally tilled corn. Soil Tillage Res. 3:135-146.

Bloom, P.R., W.M. Schuh, G.L. Malzer, W.W. Nelson, and S.D. Evans. 1982. Effect of $\mathrm{N}$ fertilizer and corn residue management on organic matter in Minnesota Mollisols. Agron. J. 74:161-163.

Bolin, B. 1977. Changes of land biota and their importance for the carbon cycle. Science 196:613-615.

Brady, N.C., and R.R. Weil. 2002. The nature and properties of soils, 13th ed. Prentice Hall, Upper Saddle River, NJ.

Brown, W.W. 1955-1963. Commercial fertilizer year book. Walter W. Brown, Atlanæa, GA.

Brown, H.M. 1996. Evaluation of nitrogen availability indices. Ph.D. thesis. Univ. of Illinois, Urbana-Champaign, IL.

Brye, K.R., S.T. Gower, J.M. Norman, and L.G. Bundy. 2002. Carbon budgets for a prairie and agroecosystems: Effects of land use and interannual variability. Ecol. Appl. 12:962-979.

Bundy, L.G., and E.S. Malone. 1988. Effect of residual profile nitrate on corn response to applied nitrogen. Soil Sci. Soc. Am. J. 52:1377-1383.

Bundy, L.G., and J.J. Meisinger. 1994. Nitrogen availability indices. p. 951984. In R.W. Weaver et al. (ed.) Methods of soil analysis. Part 2. SSSA Book Ser. 5. SSSA, Madison, WI.

Buyanovsky, G.A., and G.H. Wagner. 1998. Carbon cycling in cultivated land and its global significance. Glob. Change Biol. 4:131-141.

Campbell, C.A., K.E. Bowren, M. Schnitzer, R.P. Zentner, and L. TownleySmith. 1991. Effect of crop rotations and fertilization on soil organic matter and some biochemical properties of a thick Black Chernozem. Can. J. Soil Sci. 71:377-387.

Campbell, C.A., H.H. Janzen, and N.G. Juma. 1997. Case studies of soil quality in the Canadian Prairies: Long-term field experiments. p. 351-397. In E.G. Gregorich and M.R. Carter (ed.) Soil quality for crop production. Elsevier, Amsterdam, The Netherlands.

Campbeil, C.A., and R.P. Zentner. 1993. Soil organic matter as influenced by crop rotations and fertilization. Soil Sci. Soc. Am. J. 57:1034-1040.

Campbell, C.A., and R.P. Zentner. 1997. Crop production and soil organic matter in long-term crop rotations in the semi-arid Northern Great Plains of Canada. p. 317-334. In E.A. Paul et al. (ed.) Soil organic matter in temperate agroecosystems: Long-term experiments in North America. CRC Press, Boca Raton, FL.

Campbell, C.A., R.P. Zentner, B.-C. Liang, G. Roloff, E.G. Gregorich, and B. Blomert. 2000. Organic $C$ accumulation in soil over 30 years in semiarid southwestern Saskatchewan-Effect of crop rotations and ferrilizers. Can. J. Soil Sci. 80:179-192.

Cardwell, V.B. 1982. Fifty years of Minnesota corn production: Sources of yield increase. Agron. J. 74:984-990.

Chen, Y., S. Tessier, and J. Rouffignat. 1998. Soil bulk density estimation for tillage systems and soil textures. Trans. ASAE 41:1601-1610.

Chichester, F.W., and S.J. Smith. 1978. Disposition of ${ }^{15} \mathrm{~N}$-labeled fertilizer nitrate applied during corn culture in field lysimeters. J. Environ. Qual. 7:227-233.

Christensen, B.T. 1996. The Askov long-term experiments on animal manure and mineral fertilizers. p. 301-312. In D.S. Powlson et al. (ed.) Evaluation of soil organic matter models. NATO ASI Ser. Vol. 138. Springer-Verlag, Berlin.

Christensen, B.T., and A.E. Johnston. 1997. Soil organic matter and soil qualityLessons learned from long-term experiments at Askov and Rothamsted. p. 399-430. In E.G. Gregorich and M.R. Carter (ed.) Soil quality for crop production and ecosystem health. Elsevier, Amsterdam, The Netherlands.

Clapp, C.E., R.R. Allmaras, M.F. Layese, D.R. Linden, and R.H. Dowdy. 2000. Soil organic carbon and ${ }^{13} \mathrm{C}$ abundance as related to tillage, crop residue, and nitrogen fertilization under continuous corn management in Minnesota. Soil Tillage Res. 55:127-142.

Conde, E., M. Cardenas, A. Ponce-Mendoza, M.L. Luna-Guido, C. CruzMondragón, and L. Dendooven. 2005. The impacts of inorganic nitrogen application on mineralization of ${ }^{16} \mathrm{C}$-labelled maize and glucose, and on priming effect in saline alkaline soil. Soil Biol. Biochem. 37:681-691.

Cope, J.T., Jr., D.G. Sturkie, and A.E. Hiltbold. 1958. Effects of manure, vetch, and commercial nitrogen on crop yields and carbon and nitrogen contents of a fine sandy loam over a 30-year period. Soil Sci. Soc. Am. Proc. 22:524-527.

Crocker, G.J., and I.C.R. Holford. 1996. The Tamworth legume/cereal rotation. p. 313-317. In D.S. Powlson et al. (ed.) Evaluation of soil organic matter models. NATO ASI Ser. Vol. 138. Springer-Verlag, Berlin.

Dalal, R.C., W.M. Strong, E.J. Weston, J.E. Cooper, K.J. Lehane, A.J. King, and C.J. Chicken. 1995. Sustaining productivity of a Vertisol at Warra, Queensland, with fertilizers, no-tillage, or legumes: I. Organic matter status. Aust. J. Exp. Agric. 35:903-913.

Darmody, R.G., and T.R. Peck. 1997. Soil organic carbon changes through time at the University of Illinois Morrow Plots. p. 161-169. In E.A. Paul et al. (ed.) Soil organic matter in temperate agroecosystems: Longterm experiments in North America. CRC Press, Boca Raton, FL.

De Vos, B., M. Van Meirvenne, P. Quataert, J. Deckers, and B. Muys. 2005. Predictive quality of pedotransfer functions for estimating bulk density of forest soils. Soil Sci. Soc. Am. J. 69:500-510.

Dobermann, A., K.G. Cassman, D.T. Walters, and C. Witt. 2005. Balancing short-term and long-term goals in nutrient management. Better Crops 89(4):16-18.

Dodge, D.A., and H.E. Jones. 1948. The effect of long-time fertility treatments on the nitrogen and carbon content of a prairie soil. J. Am. Soc. Agron. 40:778-785. 
Doran, J.W., E.T. Elliot, and K. Paustian. 1998. Soil microbial activity, nitrogen cycling, and long-term changes in organic carbon pools as related to fallow tillage management. Soil Tillage Res. 49:3-18.

Dormaar, J.F, and J.M. Carefoot. 1998. Effect of straw management and nitrogen fertilizer on selected soil properties as potential soil qualiry indicators of an irrigated Dark Brown Chernozemic soil. Can. J. Soil Sci. 78:511-517.

Draycott, A.P., M.J. Durrant, and D.J. Webb. 1978. Long-term effects of fertilisers at Broom's Barn, 1971-76. p. 15-30. In Rothamsted Experimenal Stacion Report for 1977. Part 2. Lawes Agtic. Trust, Harpenden, Hers, UK.

Dyer, B. 1902. Results of investigations on the Rothamsred soils. USDA, Washington, DC.

Fierer, N., A.S. Allen, J.P. Schimel, and P.A. Holden. 2003. Controls on microbial $\mathrm{CO}_{2}$ production: A comparison of surface and subsurface horizons. Glob. Change Biol. 9:1322-1332.

Fog, K. 1988. The effect of added nitrogen on the rate of decomposition of organic matter. Biol. Rev. 63:433-462.

Follett, R.F., J.Z. Castellanos, and E.D. Buenger. 2005. Carbon dynamics and sequestration in an irrigated Vertisol in central Mexico. Soil Tillage Res. 83:148-158.

Fox, R.H., G.W. Roth, K.V. Iversen, and W.P. Piekielek. 1989. Soil and tissue nitrate tests compared for predicting soil nitrogen availability to corn. Agron. J. 81:971-974.

Gerwing, J.R., A.C. Caldwell, and L.L. Goodroad. 1979. Fertilizer nitrogen distribution under irrigation between soil, plant, and aquifer. J. Environ. Qual. 8:281-284.

Graham, R.L., R. Nelson, J. Sheehan, R.D. Perlack, and L.L. Wright. 2007. Current and potential U.S. corn stover supplies. Agron. J. 99:1-11.

Green, C.J., A.M. Blackmer, and R. Horton. 1995. Nitrogen effects on conservation of carbon during corn residue decomposition in soil. Soil Sci. Soc. Am. J. 59:453-459.

Gusser, H. 1970. Über den Einfluss hoher Stickstoffgaben auf die Zusammenserzung der organischen Substanz eines Oderbruchbodens. Albrecht-Thaer-Arch. 14:635-647.

Halvorson, A.D., B.J. Wienhold, and A.L. Black. 2002. Tillage, nitrogen, and cropping system effects on soil carbon sequestration. Soil Sci. Soc. Am. J. 66:906-912.

Harding, R.B., and E.J. Jokela. 1994. Long-term effects of forest fertilization on site organic matter and nutrients. Soil Sci. Soc. Am. J. 58:216-221.

Havlin, J.L., J.D. Beaton, S.L. Tisdale, and W.L. Nelson. 2005. Soil fertility and fertilizers: An introduction to nutrient management. 7th ed. Pearson Prentice Hall, Upper Saddle River, NJ.

Havlin, J.L., D.E. Kissel, L.D. Maddux, M.M. Claassen, and J.H. Long. 1990. Crop rotation and tillage effects on soil organic carbon and nitrogen. Soil Sci. Soc. Am. J. 54:448-452.

Hochberg, Y. 1988. A sharper Bonferroni procedure for multiple tests of significance. Biomerrika 75:800-802.

Hoef, R. G., and T. R. Peck. 2002. Soil testing and fertility. p. 91-131. In Illinois Agronomy Handbook, 23rd ed. Univ. of Illinois, UrbanaChampaign, IL.

Holechek, J.L. 1982. Fertilizer effects on above- and belowground biomass of four species. J. Range Manage. 35:39-42.

Huggins, D.R., and D.J. Fuchs. 1997. Long-term N management effects on corn yield and soil C of an Aquic Haplustoll in Minnesona. p. 121-128. In E.A. Paul et al. (ed.) Soil organic matter in temperate agroecosystems: Long-term experiments in North America. CRC Press, Boca Raton, FL.

Illinois Department of Agriculture. 1964-2005. Illinois commercial fertilizer tonnage report. Illinois Dep. of Agric., Springfield, IL.

International Atomic Energy Agency. 1970. Fertilizer management practices for maize: Results of experiments with isotopes. Tech. Rep. Ser. No. 121. IAEA, Vienna.

Ismail, I., RL. Blevins, and W.W. Frye. 1994. Long-term no-rillage effects on soil properties and continuous corn yields. Soil Sci. Soc. Am. J. 58:193-198.

Izaurralde, R.C., W.B. McGill, J.A. Robertson, N.G. Juma, and J.J. Thurston. 2001. Carbon balance of the Breton Classical Plors over half a century. Soil Sci. Soc. Am. J. 65:431-441.

Janzen, H.H., C.A. Campbell, E.G. Gregorich, and B.H. Ellert. 1997. Soil carbon dynamics in Canadian agroecosystems. p. 57-80. In R. Lal et al. (ed.) Soil processes and the carbon cycle. CRC Press, Boca Raton, FL.

Janzen, H.H., and R.M.N. Kucey. 1988. C, N, and S mineralization of crop residues as influenced by crop species and nutrient regime. Plant Soil $106: 35-41$.
Jenkinson, D.S. 1991. The Rothamsted long-term experiments: Are they still of use? Agron. J. 83:2-10.

Jenkinson, D.S., and A.E. Johnston. 1977. Soil organic matter in the Hoosfield continuous barley experiment. p. 87-101. In Rothamsted Experimental Station Report for 1976. Part 2. Lawes Agric. Trust, Harpenden, Herts, UK.

Johnson, J.M.-F., R.R. Allmaras, and D.C. Reicosky. 2006. Escimating source carbon from crop residues, roots, and rhizodeposits using the national grain-yield database. Agron. J. 98:622-636.

Johnson, J.M.-E, N.W. Barbour, and S.L. Weyers. 2007. Chemical composition of crop biomass impacts its decomposition. Soil Sci. Soc. Am. J. 71:155-162.

Johnston, A.E. 1997. The value of long-term field experiments in agricultural, ecological, and environmental research. Adv. Agron. 59:291-333.

Jokela, W.E., and G.W. Randall. 1997. Fate of ferrilizer nitrogen as affected by time and rate of application on corn. Soil Sci. Soc. Am. J. 61:1695-1703.

Khan, S.A.s R.L. Mulvaney, and R.G. Hoeft. 2001. A simple soil test for detecting sites that are nonreponsive to nitrogen fertilization. Soil Sci. Soc Am. J. 65:1751-1760.

Kiniry, J.R, J.R. Williams, R.L. Vanderlip, J.D. Atwood, D.C. Reicosky, J. Mulliken, W.J. Cox, H.J. Mascagni, Jr., S.E. Hollinger, and W.J. Wiebold. 1997. Evaluation of two maize models for nine U.S. locations. Agron. J. 89:421-426.

Kitur, B.K, M.S. Smith, R.L. Blevins, and W.W. Frye. 1984. Fate of 'sNdepleted ammonium nitrate applied to no-tillage and conventional tillage corn. Agron. J. 76:240-242.

Klapwyck, J.H., and Q.M. Ketterings. 2006. Soil tests for predicting corn response to nitrogen fertilizer in New York. Agron. J. 98:675-681.

Klapwyck, J.H., Q.M. Ketterings, G.S. Godwin, and D. Wang. 2006. Response of the Illinois Soil Nitrogen Test to liquid and composted dairy manure applications in a corn agroecosystem. Can. J. Soil Sci. 86:655-663.

Lal, R. 1986. Effects of 6 years of continuous no-till or puddling systems on soil properies and rice (Oryza sativa) yield of a loamy soil. Soil Tillage Res. 8:181-200.

Lal, R, J.M. Kimble, R.F. Folletr, and C.V. Cole. 1999. The porential of U.S. cropland to sequester carbon and mitigate the greenhouse effect. Lewis, Boca Raton, FL.

Larson, W.E., C.E. Clapp, W.H. Pierre, and Y.B. Morachan. 1972. Effects of increasing amounts of organic residues on continuous corn: II. Organic carbon, nitrogen, phosphorus, and sulfur. Agron. J. 64:204-208.

Leask, W.C., and T.B. Daynard. 1973. Dry marter yield, in vitro digestibility, percent protein, and moisture of corn stover following grain maturity. Can. J. Plant Sci. 53:515-522.

Lee, C.-K, and R.H. Bray. 1949. Organic matter and nitrogen contents of soils as influenced by management. Soil Sci. 68:203-212.

Leggert, Z.H., and D.L. Kelting. 2006. Fertilization effects on carbon pools in loblolly pine plantations on two upland sites. Soil Sci. Soc. Am. J. 70:279-286.

Lesoing, G.W., and J.W. Doran. 1997. Crop rotation, manure, and agricultural chemical effects on dryland crop yield and SOM over 16 years in eastern Nebraska. p. 197-204. In E.A. Paul et al. (ed.) Soil organic matter in temperate agroecosystems: Long-term experiments in North America. CRC Press, Boca Raton, FL

Liang, B.C., E.G. Gregorich, A.F. MacKenzie, M. Schnitzer, R.P. Voroney, C.M. Monreal, and R.P. Beryaert. 1998. Retention and turnover of corn residue carbon in some eastern Canadian soils. Soil Sci. Soc. Am. J. 62:1361-1366.

Liang, B.C., and A.F MacKenzie. 1992. Changes in soil organic carbon and nitrogen after six years of corn production. Soil Sci. 153:307-313.

Liao, W., Y. Liu, C. Liu, Z. Wen, and S. Chen. 2006. Acid hydrolysis of fbers from dairy manure. Bioresour. Technol. 97:1687-1695.

Liebig, M.A., G.E. Varvel, J.W. Doran, and B.J. Wienhold. 2002. Crop sequence and nitrogen fertilization effects on soil properties in the western Corn Belt. Soil Sci. Soc. Am. J. 66:596-601.

Lory, J.A, and P.C. Scharf. 2003. Yield goal versus delta yield for predicting fertilizer nitrogen need in corn. Agron. J. 95:994-999.

Lyon, T.L., H.O. Buckman, and N.C. Brady. 1952. The nature and properties of soils. 5th ed. Macmillan, New York.

Machado, S., K. Rhinhart, and S. Perrie. 2006. Long-term cropping system effects on carton sequestration in eastern Oregon. J. Environ. Qual. 35:1548-1553.

Mack, M.C., E.A.G. Schuur, M.S. Bret-Harte, G.R. Shaver, and F.S. Chapin, III. 2004. Ecosystem carbon storage in arctic tundra reduced by longterm nutrienr fertilization. Nature 431:440-443. 
Magdoff, F, D. Ross, and J. Amadon. 1984. A soil test for nitrogen availability to corn. Soil Sci. Soc. Am. J. 48:1301-1304.

Malhi, S.S., J.T. Harapiak, M. Nyborg, K.S. Gill, and N.A. Flore. 2002. Autumn and spring applications of ammonium nitrate and urea to bromegrass influence total and light fraction organic $C$ and $N$ in a thin Black Chernozem. Can. J. Soil Sci. 82:211-217.

Malhi, S.S., M. Nyborg, J.T. Harapiak, K. Heier, and N.A. Flore. 1997. Increasing organic $C$ and $N$ in soil under bromegrass with long-term $N$ fertilization. Nutr. Cycling Agroecosyst. 49:255-260.

Martin, J.H., W.H. Leonard, and D.L. Stamp. 1976. Principles of field crop production. 3rd ed. Macmillan, New York.

McAndrew, D.W., and S.S. Malhi. 1992. Long-term N fertilization of a solonetzic soil: Effects on chemical and biological properties. Soil Biol. Biochem. 24:619-623.

McFarland, M., D. Devlin, R. Koenig, and D. Osmond. 2005. Comparison of land grant university soil test recommendations for nitrogen, phosphorus and potassium. Available at http://srwqis.tamu.edu/downloads/LGU. NMRecommendation.Summary.8.05.pdf (verified 19 June 2007).

McSwiney, C.P., and G.P. Robertson. 2005. Nonlinear response of $\mathrm{N}_{2} \mathrm{O}$ flux to incremental fertilizer addition in a continuous maize (Zea mays L.) cropping system. Glob. Change Biol. 11:1712-1719.

Mebius, L.J. 1960. A rapid method for the determination of organic carbon in soil. Anal. Chim. Acta 22:120-124.

Meisinger, J.J., V.A. Bandel, J.S. Angle, B.E. O'Keefe, and C.M. Reynolds. 1992. Presidedress soil nitrate test evaluation in Maryland. Soil Sci. Soc. Am. J. 56:1527-1532.

Melsted, S.W. 1954. New concepts of management of Corn Belt soils. Adv. Agron. 6:121-142.

Millar, C.E., and L.M. Turk. 1951. Fundamentals of soil science. 2nd ed. John Wiley \& Sons, New York.

Mitchell, C.C., R.L. Westerman, J.R. Brown, and T.R. Peck. 1991. Overview of long-term agronomic research. Agron. J. 83:24-29.

Motavalli, P.P., L.G. Bundy, T.W. Andraski, and A.E. Peterson. 1992. Residual effects of long-term nitrogen fertilization on nitrogen availability to corn. J. Prod. Agric. 5:363-368.

Mulvaney, RL., S.A. Khan, and T.R. Ellsworth. 2006. Need for a soilbased approach in managing nitrogen fertilizers for profitable corn production. Soil Sci. Soc. Am. J. 70:172-182.

Mulvaney, R.L., S.A. Khan, R.G. Hoeft, and H.M. Brown. 2001. A soil organic nitrogen fraction that reduces the need for nitrogen fertilization. Soil Sci. Soc. Am. J. 65:1164-1172.

Nyborg, M., S.S. Malhi, E.D. Solberg, and R.C. Izaurralde. 1999. Carbon storage and light fraction $\mathrm{C}$ in a grassland Dark Gray Chernozem soil as influenced by $N$ and $S$ ferrilization. Can. J. Soil Sci. 79:317-320.

Nyborg, M., E.D. Solberg, S.S. Malhi, and R.C. Izaurralde. 1995. Fertilizer $\mathrm{N}$, crop residue, and tillage alter soil $\mathrm{C}$ and $\mathrm{N}$ content in a decade. p. 93-99. In $\mathrm{R}$. Lal et al. (ed.) Soil management and the greenhouse effect. Lewis Publishers, Boca Raton, FL.

Odell, R.T., S.W. Melsted, and W.M. Walker. 1984. Changes in organic carbon and nitrogen of Morrow Plot soils under different treatments, 1904-1973. Soil Sci. 137:160-171.

Odell, R.T., W.M. Walker, L.V. Boone, and M.G. Oldham. 1982. The Morrow Plots: A century of learning. Bull. 775. Univ. of Illinois, Urbana-Champaign, IL.

Olson, R.V. 1980. Fate of tagged nitrogen fertilizer applied to irrigated corn. Soil Sci. Soc. Am. J. 44:514-517.

Olson, K.R., J.M. Lang, and S.A. Ebelhar. 2005. Soil organic carbon changes after 12 years of no-tillage and tillage of Grantsburg soils in southern Illinois. Soil Tillage Res. 81:217-225.

Omay, A.B., C.W. Rice, L.D. Maddux, and W.B. Gordon. 1998. Corn yield and nitrogen uptake in monoculture and in rotation with soybean. Soil Sci. Soc. Am. J. 62:1596-1603.

Parker, F.W. 1946. The nitrogen problem in soil management. J. Am. Soc. Agron. 38:283-291.

Peters, S.E., M.M. Wander, L.S. Saporito, G.H. Harris, and D.B. Friedman. 1997. Management impacts on SOM and related soil properties in a longterm farming systems trial in Pennsylvania: 1981-1991. p. 183-196. In E. A. Paul et al. (ed.) Soil organic matter in temperate agroecosystems: Longterm experiments in North America. CRC Press, Boca Raton, FL.

Pikul, J.L., Jr., T.E. Schumacher, and M. Vigil. 2001. Nitrogen use and carbon sequestered by corn in the northern Corn Belt, U.S. TheScientificWorld 1:707-713.
Post, W.M., and K.C. Kwon. 2000. Soil carbon sequestration and land-use change: Processes and potential. Glob. Change Biol. 6:317-327.

Potter, K.N., H.A. Torbert, O.R. Jones, J.E. Matocha, J.E. Morrison, Jr., and P.W. Unger. 1998. Distribution and amount of soil organic C in longterm management systems in Texas. Soil Tillage Res. 47:309-321.

Powlson, D. 2005. Will soil amplify climate change? Nature 433:204-205.

Prince, S.D., J. Haskett, M. Steininger, H. Strand, and R. Wright. 2001. Net primary production of U.S. Midwest croplands from agricultural harvest yield data. Ecol. Appl. 11:1194-1205.

Rasmussen, P.E., R.R. Allmaras, C.R. Rohde, and N.C. Roager, Jr. 1980. Crop residue influences on soil carbon and nitrogen in a wheat-fallow system. Soil Sci. Soc. Am. J. 44:596-600.

Rasmussen, P.E., and W.J. Parton. 1994. Long-term effects of residue management in wheat-fallow: I. Inputs, yield, and soil organic matter. Soil Sci. Soc. Am. J. 58:523-530.

Rasmussen, P.E., and R.W. Smiley. 1997. Soil carbon and nitrogen change in long-term agricultural experiments at Pendleton, Oregon. p. 353--360. In E.A. Paul (ed.) Soil organic matter in temperate agroecosystems: Long-term experiments in North America. CRC Press, Boca Raton, FL.

Raun, W.R., G.V. Johnson, S.B. Phillips, and R.L. Westerman. 1998. Effect of long-term $N$ fertilization on soil organic $C$ and total $N$ in continuous wheat under conventional tillage in Oklahoma. Soil Tillage Res. 47:323-330.

Reddy, G.B., and K.R. Reddy. 1993. Fate of nitrogen-15 enriched ammonium nitrate applied to corn. Soil Sci. Soc. Am. J. 57:111-115.

Reetz, H.F., Jr., T.R. Peck, and M.G. Oldham. 1989. Long-term evidence for sound fertility management. Better Crops 74(1):18-20.

Reicosky, D.C., S.D. Evans, C.A. Cambardella, R.R. Ailmaras, A.R. Wilts, and D.R. Huggins. 2002. Continuous corn with moldboard tillage: Residue and fertility effects on soil carbon. J. Soil Water Conserv. 57:277-284.

Reinertsen, S.A., L.F. Elliott, V.L. Cochran, and G.S. Campbell. 1984. Role of available carbon and nitrogen in determining the rate of wheat straw decomposition. Soil Biol. Biochem. 16:459-464.

Reitemeier, R.F. 1943. Semimicroanalysis of saline soil solutions. Ind. Eng. Chem., Anal. ed. 15:393-402.

Robinson, CA, RM. Cruse, and M. Ghaffarzadeh. 1996. Cropping system and nitrogen effects on Mollisol organic carbon. Soil Sci. Soc. Am. J. 60:264-269.

Roth, G.W., and R.H. Fox. 1990. Soil nitrate accumulations following nitrogen-fertilized corn in Pennsylvania. J. Environ. Qual. 19:243-248.

Rovira, P., and V.R. Vallejo. 1997. Organic carbon and nitrogen mineralization under Mediterranean climatic conditions: The effects of incubation depth. Soil Biol. Biochem. 29:1509-1520.

Ruffo, M.L., G.A. Bollero, D.S. Bullock, and D.G. Bullock. 2006. Site-specific production functions for variable rate corn nitrogen fertilization. Precis. Agric. 7:327-342.

Russell, A.E., D.A. Laird, T.B. Parkin, and A.P. Mallarino. 2005. Impact of nitrogen fertilization and cropping system on carbon sequestration in Midwestern Mollisols. Soil Sci. Soc. Am. J. 69:413-422.

Russell, M.B. 1956. All the way back in one year? Plant Food Rev. 2(1):18-19.

Sainju, U.M., B.P. Singh, and W.F. Whitehead. 2002. Long-term effects of tillage, cover crops, and nitrogen fertilization on organic carbon and nitrogen concentrations in sandy loam soils in Georgia, USA. Soil Tillage Res. 63:167-179.

Sainju, U.M., B.P. Singh, and W.F. Whitehead. 2005. Tillage, cover crops, and nitrogen fertilization effects on cotton and sorghum root biomass, carbon, and nitrogen. Agron. J. 97:1279-1290.

Sainju, U.M., B.P. Singh, W.F. Whitehead, and S. Wang. 2006. Carbon supply and storage in tilled and nontilled soils as influenced by cover crops and nitrogen fertilization. J. Environ. Qual. 35:1507-1517.

SAS Institute. 2007. SAS Onlinedoc 9.1.3. SAS Inst., Cary, NC. Available at http:// support.sas.com/onlinedoc/913/docMainpage.jsp (verified 19 June 2007).

Schlesinger, W.H. 2000. Carbon sequestration in soils: Some caution amidst optimism. Agric. Ecosyst. Environ. 82:121-127.

Schmitt, M.A., and G.W. Randall. 1994. Developing a soil nitrogen test for improved recommendations for corn. J. Prod. Agric. 7:328-334.

Smith, G.E. 1942. Sanborn Field: Fifty years of experiments with crop rotations, manure and fertilizers. Missouri Agric. Exp. Stn. Bull, 458. Univ. of Missouri, Columbia, MO.

Solberg, E.D., M. Nyborg, R.C. Izaurralde, S.S. Malhi, H.H. Janzen, and M. Molina-Ayala. 1997. Carbon storage in soils under continuous cereal grain cropping: $\mathrm{N}$ fertilizer and straw. p. 235-254. In R. Lal et al. (ed.) Management of carbon sequestration in soil. CRC Press, Boca Raton, FL. 
Soon, Y.K., and M.A. Arshad. 2002. Comparison of the decomposition and $\mathrm{N}$ and $\mathrm{P}$ mineralization of canola, pea, and wheat residues. Biol. Fertil. Soils 36:10-17.

Starkey, R.L. 1924. Some observations on the decomposition of organic matter in soils. Soil Sci. 17:293-314.

Stevens, W.B., R.G. Hoeft, and R.L. Mulvaney. 2005. Fate of nitrogen-15 in a long-term nitrogen rate study: II. Nitrogen uptake efficiency. Agron. J. 97:1046-1053.

Tate, R.L., III. 1987. Soil organic matter: Biological and ecological effects. Wiley-Interscience, New York.

Timmons, D.R., and R.M. Cruse. 1990. Effect of fertilization method and tillage on nitrogen-15 recovery by corn. Agron. J. 82:777-784.

Tisdale, S.L., and W.L. Nelson. 1956. Soil fertility and ferrilizers. Macmillan, New York.

Tollenaar, M., A. Ahmadzadeh, and E.A. Lee. 2004. Physiological basis of heterosis for grain yield in maize. Crop Sci. 44:2086-2094.

Torbert, H.A., R.G. Hoeft, R.M. Vanden Heuvel, R.L. Mulvaney, and S.E. Hollinger. 1993. Short-term excess water impact on corn yield and nitrogen recovery. J. Prod. Agric. 6:337-344.

Tóth, B. 1977. The effect of nutritive conditions on the decomposition of corn-stalk. p. 225-228. In J. Szegi (ed.) Soil biology and conservation of the biosphere. Akadémiai Kiado, Budapest, Hungary.

Tran, T.S., M. Giroux, and M.P. Cescas. 1997. Urilisation de l'engrais azoté marqué au ${ }^{15} \mathrm{~N}$ par le maïs selon les modes d'applicarion er les doses d'azote. Can. J. Soil Sci. 77:9-19.

United States Department of Agriculture. 2007. USDA National Agricultural Statistics Service. Available at http://www.nass.usda.gov (verified 30 July 2007).

VandenBygaart, A.J., and D.A. Angers. 2006. Towards accurate measurements of soil organic carbon stock change in agroecosystems. Can. J. Soil Sci. 86:465-471.

VandenBygaart, A.J., X.M. Yang, B.D. Kay, and J.D. Aspinall. 2002. Variability in carbon sequestration potential in no-till soil landscapes of southern Ontario. Soil Tillage Res. 65:231-241.

Vanotti, M.B., L.G. Bundy, and A.E. Peterson. 1997. Nitrogen fertilizer and legume-cereal rotation effects on soil productivity and organic matter dynamics in Wisconsin. p. 105-119. In E.A. Paul er al. (ed.) Soil organic matter in temperate agroecosystems: Long-term experiments in North America. CRC Press, Boca Raton, FL.

Varvel, G.E. 1994. Rotation and nitrogen fertilization effects on changes in soil carbon and nitrogen. Agron. J. 86:319-325.

Varvel, G.E. 2006. Soil organic carbon changes in diversifed rotations of the western Corn Belt. Soil Sci. Soc. Am. J. 70:426-433.

Vigil, M.F, and D. Sparks. 1995. Factors affecting the rate of crop residue decomposition under field conditions. Conserv. Till. Fact Sheet \#3-95. USDA-ARS, Akron, CO.

Vitosh, M.L., R.E. Lucas, and G.H. Silva. 1997. Long-term effects of ferrilizer and manure on corn yield, soil carbon, and other soil chemical properties in Michigan. p. 129-139. In E.A. Paul et al. (ed.) Soil organic matter in temperate agroecosystems: Long-term experiments in North America. CRC Press, Boca Raton, FL.

Waksman, S.A., and F.G. Tenney. 1928. Composition of narural organic materials and their decomposition in the soil: III. The influence of nature of plant upon the rapidity of its decomposition. Soil Sci. 26:155-171.

Wander, M.M., S.J. Traina, B.R Stinner, and S.E. Peters. 1994. Organic and conventional management effects on biologically active soil organic matter pools. Soil Sci. Soc. Am. J. 58:1130-1139.

West, T.O., and WM. Post. 2002. Soil organic carbon sequestration rates by tillage and crop romion: A global dara analysis. Soil Sci. Soc. Am. J. 66:1930-1946.

White, J.W. 1927. Soil organic matter and manurial treatments. J. Am. Soc. Agron. 19:389-396.

Williams, J.D., C.R. Crozier, J.G. White, R.P. Sripada, and D.A. Crouse. 2007. Comparison of soil nitrogen tests for corn fertilizer recommendations in the humid southeastern USA. Soil Sci. Soc. Am. J. 71:171-180.

Wilts, A. R., D. C. Reicosky, R. R. Allmaras, and C. E. Clapp. 2004. Longterm corn residue effects: Harvest alternatives, soil carbon turnover, and roar-derived carbon. Soil Sci. Soc. Am. J. 68:1342-1351.

Wolf, B. 1999. The ferrile triangle: The interrelarionship of air, water, and nutrients in maximizing soil productivity. Food Products Press, Binghamton, NY. 


\section{COPYRIGHT INFORMATION}

TITLE: The Myth of Nitrogen Fertilization for Soil Carbon Sequestration

SOURCE: Journal of Environmental Quality 36 no6 N/D 2007

PAGE(S): $1821-32$

The magazine publisher is the copyright holder of this article and it is reproduced with permission. Further reproduction of this article in violation of the copyright is prohibited. To contact the publisher:

http://www.agronomy.org/ 